\title{
Invasive alien plant species in unmanaged forest reserves, Austria
}

\author{
Katharina Lapin', Janine Oettel', Herfried Steiner', Magdalena Langmaier', \\ Dunja Sustic', Franz Starlinger', Georg Kindermann', Georg Frank' \\ I Austrian Federal Research Centre for Forests, Natural Hazards and Landscape (Bundesforschungs- und Au- \\ sbildungszentrum für Wald, Naturgefahren und Landschaft (BFW)), Seckendorff-Gudent-Weg 8, 1131 Vien- \\ na, Austria \\ Corresponding author: Katharina Lapin (katharina.lapin@bfw.gv.at)
}

Academic editor: Franz Essl | Received 25 March 2019 | Accepted 22 May 2019 | Published 15 July 2019

Citation: Lapin K, Oettel J, Steiner H, Langmaier M, Sustic D, Starlinger F, Kindermann G, Frank G (2019) Invasive alien plant species in unmanaged forest reserves, Austria. NeoBiota 48: 71-96. https://doi.org/10.3897/neobiota.48.34741

\begin{abstract}
Invasive alien plant species (IAS) are one of the greatest threats to global biodiversity and the sustainable functioning of ecosystems and mitigating the threat posed by them is therefore of great importance. This study presents the results of a 15-year investigation into how IAS occur within natural forest reserves (NFR): unmanaged forest ecosystems within Austria, concluding that unmanaged forests are not resistant to plant invasions. The study comprised ground vegetation, regeneration, and stand structure surveys. The presence or absence of IAS in different forest types was assessed and the influencing variables for their presence or absence were determined. In addition, the study analysed whether the abundance of IAS has increased at the site level within the past decade. Significant differences in the probability of IAS presences between forest types (photosociological alliances) were found. The results of the study show that natural riparian and floodplain forests are among the forest types most vulnerable to biological invasions, which is reflected in elevation and soil type being determined as the main factors influencing the spread of IAS in unmanaged forests. The results of this study may be useful for persons responsible for sustainable forest management programmes or for managing forested areas within national parks. They provide a case study on non-intervention forest management policy in order to mitigate the impacts of IAS in protected areas. Forest areas, where IAS begin to spread can be identified, which in turn leads to measures in the early stages of invasion, and to optimise monitoring and control measures for relevant species in Central European forest types.
\end{abstract}

\section{Keywords}

Austria, biological invasions, forest ecosystems, floodplains, natural forest reserves, nature conservation, neophytes

Copyright Katharina Lapin et al. This is an open access article distributed under the terms of the Creative Commons Attribution License (CC BY 4.0), which permits unrestricted use, distribution, and reproduction in any medium, provided the original author and source are credited. 


\section{Introduction}

Invasive alien plant species (hereinafter "IAS") are one of the greatest threats to global biodiversity and the sustainable functioning of ecosystems (Perrings et al. 2010). Mitigating the threats posed by IAS has therefore become a major topic for consideration by conventions, many international organisations, non-governmental organisations (NGOs), governments, and local communities (EU Regulation 2014; CBD 2016; IUCN 2018). Managing the spread of IAS in forest ecosystems requires action from stakeholders directly involved in the conservation of forests as well as from those using forests for trade, health, or tourism (Brundu and Richardson 2016).

Databases and platforms such as the Global Register of Introduced and Invasive Species (GRIIS) have been established to collate information on the distribution of IAS for use by decision makers to plan and manage the spread of IAS (CABI 2019; GBIF 2019; GISD 2019; GRIS 2019). Measures for controlling the spread of IAS are often an integral part of forest management plans that aim to sustain and develop biodiversity-rich forest ecosystems and sustainable timber production systems (Pagad et al. 2015; Brundu and Richardson 2016).

In total, $42 \%$ (167 million ha) of the land surface of the EU is covered in forests, and preventing, controlling at early stages of invasion, and managing the spread of IAS in Europe's protected forest areas is therefore of particular importance for insuring ecosystem services of European forests (The EU Forest Strategy 2013). Approximately $21 \%\left(375,000 \mathrm{~km}^{2}\right)$ of Europe's forests are included in the NATURA 2000 network, the largest network of protected areas in the world extending across all $28 \mathrm{EU}$ countries (EEA 2018). Structured forest management systems have shaped the development of forest ecosystems within the NATURA 2000 network for centuries (Bastian 2013; European Commission 2015). IAS are among the severest threats to the biodiversity and ecosystem functions of European protected forest areas (Chirici et al. 2014; Seidl et al. 2014; Guerra et al. 2018). Protected forests are well-established across Europe, whilst unmanaged woodlands and primary natural forests are very rare (FAO 2015; Potapov et al. 2017). It is estimated that primary forests constitute only $0.7 \%$ ( 1.4 million ha) of the total European forest cover (Sabatini et al. 2018), and very few data on the distribution of IAS in these unmanaged natural or primary forest are reported. For example, a study in the Białowiez a primeval forest in north-eastern Poland recorded the presence of the alien plant species Impatiens parviflora in similar abundance to managed forests in Lower Saxony and North Hesse, Germany (Chmura 2004; Chmura and Sierka 2007 ; Adamowski 2008; Schmidt 2012).

From previous studies we can conclude that alien species also occur in many unmanaged forests and that they are often invaded by similar sets of alien species (Foxcroft et al. 2013). Nevertheless, it was assumed that unmanaged forests are generally more resistant to invasion than managed forests with high levels of human disturbance 
(Rejmánek and Richardson 1996; Levine et al. 2004). It is, however, difficult to compare the spread of IAS in managed and unmanaged forests, as almost all forests in Europe have been managed for centuries. The difficulties in comparing these two types regarding any species invasion should be addressed.

Looking at Austria in particular, the proportion of land surface covered in forests is $47.9 \%$ ( 4.02 million ha), well above the EU-wide proportion. About $88 \%$ of this area (3.53 million ha) consists of managed productive forest (BFW 2019). The Austrian National Forest Inventory reports an average proportion of alien tree species of less than $2 \%$ in Austria (NFI 2009). The alien tree species most commonly occurring in the forest inventory areas during the most recent inventory period (2007-2009) were hybrid poplars, Douglas fir, and Robinia pseudoacacia.

The study area comprises the Austrian natural forest reserves (hereinafter "NFR") as historically managed and now unmanaged forest sites, which provide novel areas for research, training, and education on forests. The aim of the NFR programme is to conserve, enhance, and monitor forest biodiversity by abstaining from forest utilisation, logging of dead wood, and artificial regeneration of forest trees (Frank and Müller 2003; BFW 2018). The sites will be used to add further information on the spread of IAS in Central European forest ecosystems. This is highly relevant for the implementation of transnational early warning systems and local alert lists (Smith et al. 2008; Kettunen et al. 2009; National Pest Control Agencies 2015).

Few studies have been conducted with the aim of understanding how human activity in forests causes changes in the presence of IAS. Validated knowledge on forest regeneration and tending, tree species selection, regeneration procedures, production and regeneration periods, competition control, and natural selection and differentiation in particular is needed to be able to compare the production, protection and recreation provided by forests depending on their ecological conditions. This type of information would help forest managers to identify forest regions or stands where IAS start to spread, which in turn gives rise for action in the early stages of invasion and optimise monitoring and control measures concerning the relevant species for Central European forest types.

This paper develops the current literature on IAS by providing an analysis of the alien flora in unmanaged NFR in Austria. The aims are (i) to identify invasive plant species in NFR and (ii) to analyse which variables are important for determining the presence or absence of IAS across multiple NFR, with particular reference to (iii) the composition of native plant species in those NFR. Additionally, the paper analyses at the site level (iv) whether the abundance of invasive alien plant species has increased within the past 15 years. The results of this paper are particularly useful for assessing "zero-IAS-management-scenarios" in forests, which is an ongoing challenge for persons responsible for sustainable forest management programmes or managing forested areas within national parks, by providing information on the spread of IAS in different unmanaged forest types. 


\section{Method}

\section{Study area}

The NFR analysed for this study are part of the Austrian Natural Forest Reserve Programme established in 1995. Sites in formerly managed forest areas were selected according to a set of criteria including naturalness of tree species composition. Today, the NFR network comprises 192 reserves in Austria with a total area of 8,355 ha. The aim of the programme is to represent the 118 forest communities (out of 159 known forest and shrub communities) found in 22 growth zones within Austria (Kilian et al. 1994; Frank 2003; Willner and Grabherr 2007); it currently covers 84 of the 118 relevant forest communities. It is important to realise that the investigated NFR sites are unique observational plots representing unmanaged natural forest ecosystems and therefore not representative of the typical Austrian forest cover - 47.9\% (4.02 million ha) of the area of Austria are covered in forests, with $88 \%$ of this area (3.53 million ha) consisting of managed productive forest (BFW 2019).

\section{Data sampling}

\section{a) Vegetation sampling}

The ground vegetation was recorded in 2,344 sample plots with sizes varying from 50 to $700 \mathrm{~m}^{2}$ (average size: $240 \mathrm{~m}^{2}$ ) across all 192 NFR sites using the Braun-Blanquet cover abundance scale with 7 to 9 classes (Braun-Blanquet 1928, 1932; Moore 1962; Londo 1976). The sample plots were distributed representatively across the occurring forest communities of each NFR site. For the analysis of the presence or absence of IAS in each of the 2,344 sample plots, forest communities were summarized into forest associations according to the classification by Willner and Grabherr (2007).

\section{b) Tree sampling}

The composition and development of tree species was systematically determined for the sampling plots within the NFR using Bitterlich's angle count (AC) sampling with a basal area factor (BAF) of 4 (Bitterlich 1984). No threshold was defined for the diameter at breast height $(\mathrm{DBH})$. Only NFR with repeated surveys were relevant for the analysis (784 AC plots in $36 \mathrm{NFR}$ ). The only sample areas with a proportion of IAS in the AC sampling were those in the floodplain forest community Fraxino pannonicaeUlmetum (Soó in Aszód 1936 corr. Soó 1963) located alongside the river March in Lower Austria. Accordingly, the analysis of tree species development focused on floodplain forests. This March floodplain study site covers an area of 91 hectares (64 plots in 6 NFR) at an elevation of 140 to $150 \mathrm{~m}$ above sea level. The Fraxino pannonicaeUlmetum community typically occurs in the broad floodplains of lowland rivers and is dominated by Fraxinus angustifolia, with Acer campestre, Carpinus betulus, Ulmus laevis, and Ulmus minor also commonly appearing (Douda et al. 2016). 
The first data collection took place between 1997 and 1999 (period 1), and the survey was repeated 15 years later between 2013 and 2014 (period 2). The collected data included tree-related information like species, DBH, tree height, crown height, and location within the plot (distance and direction). For the analysis of tree species composition and development, the stem number $(\mathrm{N})$ and basal area $(\mathrm{G})$ per hectare were determined. The number of trees per hectare $(\mathrm{N})$ was calculated by dividing the BAF $(\mathrm{BAF}=4)$ by the circular area represented by each tree. The basal area per hectare $(\mathrm{G})$ was calculated by summing up the trees in the $\mathrm{AC}$ and multiplying them with the BAF.

\section{c) Regeneration sampling}

Natural regeneration in the NFR was investigated from 2013 onward, and information is available for 36 NFR (784 samples). On each sample plot, 4 satellite samples of $1 \mathrm{~m}^{2}$ in size ( $4 \mathrm{~m}^{2}$ per plot) were collected to document the regeneration of tree species. Tree species, height (in $10 \mathrm{~cm}$ increments) and browsing damage were determined for each recorded plant. For the analysis of tree species regeneration, the number of regeneration trees per hectare was calculated by multiplying the number of trees with 2,500 .

\section{Data processing and analysis}

Each of the alien plant species found in the 192 NFR was evaluated to determine its invasive potential in Austrian bioregions as well as at the European level and to estimate the likelihood of its future spread and negative ecological impact in Austrian forests (Essl et al. 2002; Fischer 2008; Lauber and Wagner 2008; GISD 2018; Landolt et al. 2010; CABI 2019; European Commission 2019; GRIS 2019). This approach yielded two groups of alien plant species in Austria (Table 1): invasive alien plant species (IAS) and non-invasive alien plant species (AS). The variables correlating with the presence of IAS and AS in NFR were documented for each sample plot ( $n=2,344$, Table 2$)$ and subsequently added in based on their importance according to literature (Mucina 1993; Essl et al. 2002; Willner and Grabherr 2007; Fischer 2008). Only IAS were considered for further statistical analysis.

To prevent possible autocorrelations between the sometimes heavily spatially clustered vegetation recordings, neighbouring vegetation recordings were conflated into a single unit, with a threshold distance of $2 \mathrm{~km}$ defined for this purpose. This distance is based on the close proximity of six NFR located in the lower March floodplains in a $4.5 \mathrm{~km}$ radius. Although the distances between some individual areas is nearly 2 $\mathrm{km}$, their specific species composition, especially that of alien species, is owed to their spatial proximity according to expert opinion. They were therefore aggregated into a single NFR site. This aggregation of neighbouring NFR was pragmatically extended to all other NFR as well, which provides the additional advantage of increasing the number of observations per NFR unit of area. In all, 21 groups of two NFR, five groups of three NFR, three groups of five NFR, two groups of six NFR, and one group of seven 
Table I. List of invasive alien plant species (IAS) and non-invasive alien plant species (AS) in NFR. The 16 invasive alien plant species with their family, life form (Raunkiær system), native range, number of NFR with occurrence.

\begin{tabular}{c|l|l|c|c|c}
\hline$\#$ & \multicolumn{1}{|c|}{ Family } & \multicolumn{1}{c|}{ Species } & Life form (Raunkiær system) & Native range & $\begin{array}{c}\text { number } \\
\text { of NFR }\end{array}$ \\
\hline \multicolumn{2}{|c|}{ Invasive alien species } & & & \\
\hline 1 & Balsaminaceae & Impatiens parviflora DC. & Therophyte & Asia & 42 \\
\hline 2 & Fabaceae & Robinia psendoacacia L. & Phanaerophyte & Northern America & 16 \\
\hline 3 & Compositae & Solidago gigantea Aiton & Therophyte & Asia & 6 \\
\hline 4 & Balsaminaceae & Impatiens glandulifera Royle & Phanaerophyte & Northern America & 4 \\
\hline 5 & Sapindaceae & Acer negundo L. & Therophyte & Northern America & 4 \\
\hline 6 & Compositae & Bidens frondosa L. & Phanaerophyte & Northern America & 4 \\
\hline 7 & Oleaceae & Fraxinus pennsylvanica Marshall & Geophyte & Northern America & 2 \\
\hline 8 & Compositae & $\begin{array}{l}\text { Symphyotrichum lanceolatum } \\
\text { (Willd.) G.L.Nesom }\end{array}$ & Phanaerophyte & Asia & 1 \\
\hline 9 & Simaroubaceae & Ailanthus altissima (Mill.) Swingle & Phanaerophyte & Asia & 1 \\
\hline 10 & Elaeagnaceae & Elaeagnus angustifolia L. & Hemikryptophyte-Therophyte & Northern America & 1 \\
\hline 11 & Compositae & Erigeron annuus (L.) Pers. & Therophyte & Northern America & 1 \\
\hline 12 & Compositae & Erigeron canadensis L. & Geophyte-Hemikryptophyte & Northern America & 1 \\
\hline 13 & Phytolaccaceae & Phytolacca americana L. & Geophyte & Asia & 1 \\
\hline 14 & Polygonaceae & Reynoutria japonica Houtt. & Hemikryptophyte & Northern America & 1 \\
\hline 15 & Compositae & Solidago canadensis L. & Geophyte & Northern America & 1 \\
\hline 16 & Compositae & $\begin{array}{l}\text { Symphyotrichum novi-belgii } \text { (L.) } \\
\text { G.L.Nesom }\end{array}$ & & & 1 \\
\hline
\end{tabular}

Non-invasive alien species

\begin{tabular}{l|l|l|c|c|c}
\hline 17 & Fagaceae & Quercus rubra L. & Phanaerophyte & Northern America & 3 \\
\hline 18 & Sapindaceae & Aesculus hippocastanum L. & Phanaerophyte & Southeastern Europe & 2 \\
\hline 19 & Amaranthaceae & Atriplex sagittata Borkh. & Therophyte & Southwestern Asia & 2 \\
\hline 20 & Compositae & Erechtites hieraciifolia (L.) Raf. ex DC. & Therophyte & America & 2 \\
\hline 21 & Amaranthaceae & Atriplex prostrata Boucher ex DC. & Therophyte & Western Europe & 1 \\
\hline 22 & Cucurbitaceae & $\begin{array}{l}\text { Echinocystis lobata } \text { (Michx.) } \\
\text { Torr. \& A.Gray }\end{array}$ & Therophyte & Northern America & 1 \\
\hline 23 & Onagraceae & Epilobium ciliatum Raf. & Hemikryptophyte & Northern America & 1 \\
\hline 24 & Compositae & Galinsoga quadriradiata Ruiz \& Pav. & Therophyte & Northern America & 1 \\
\hline 25 & Leguminosae & Lupinus polyphyllus Lindl. & Hemikryptophyte & Northern America & 1 \\
\hline 26 & Moraceae & Morus alba L. & Phanaerophyte & Asia & 1 \\
\hline 27 & Oxalidaceae & Oxalis stricta L. & Geophyte-Therophyte & Northern America & 1 \\
\hline 28 & Pinaceae & Pinus strobus L. & Phanaerophyte & Northern America & 1 \\
\hline 29 & Salicaceae & Populus balsamifera L. & Phanaerophyte & Northern America & 1 \\
\hline 30 & Salicaceae & Populus $\times$ canadensis Moench & Phanaerophyte & Northern America & 1 \\
\hline 31 & Rosaceae & Potentilla indica (Jacks.) Th.Wolf & Hemikryptophyte & Asia & 1 \\
\hline 32 & Rosaceae & Rhodotypos scandens (Thunb.) Makino & Phanaerophyte & Asia & 1 \\
\hline 33 & Compositae & Telekia speciosa (Schreb.) Baumg. & Geophyte-Hemikryptophyte & Southeastern Europe & 1 \\
\hline 34 & Ericaceae & Vaccinium macrocarpon Aiton & Chamaephyte & Northern America & 1 \\
\hline
\end{tabular}

NFR were aggregated, while 101 NFR remain as individual sites. The 192 NFR were thus reduced to 133 NFR sites. Furthermore, the presence/absence data for each observation were weighted by the number of observations in each NFR site (weights $=1 / n$ ).

The relationship between the explanatory variables and the presence of IAS in the NFR was analysed for all 16 IAS together, as well as separately for Impatiens parviflora 
Table 2. Explanatory variables (alliance, soil type, elevation, exposition, inclination, bedrock class, soil layer depth, and relief) used for the quasi-binomial logistic regression and the Random Forest model of the presence and absence of IAS in 2344 sample plots in 192 NFR.

\begin{tabular}{l|c|c|c}
\hline \multicolumn{1}{c|}{ Variable } & Classification & Range/Categories & Description \\
\hline Alliance & Categorical & $\mathrm{N}=21$ categories & Root category of phytosociological associations (Willner and \\
Grabherr 2007).
\end{tabular}

and Robinia pseudoacacia, using generalized linear models (GLM) with a logit link function. This analysis was performed using the freeware $R$ ( $\mathrm{R}$ version 3.4.2 (201709-28)) for personal computers (R Core Team 2017). Categorical and continuous data were included in regression models as variables (Table 2), and the most common category was used as the reference category (Press and Wilson 1978). Quasi-binomial logistic regression was applied to investigate which variables were significant for predicting the presence or absence of invasive plants in NFR. The independent candidate variables were alliance, soil type, bedrock class, relief, elevation, soil layer depth, exposition, and inclination. The statistical significance of individual predictors was tested using Pearson's chi-squared test with a significance level of $<0.05$. Several subsequent analyses were run until a minimal final model containing only significant explanatory variables was achieved. After performing the chi-squared test with $95 \%$ confidence intervals, the following explanatory variables were used in the final quasi-binomial logistic regression: soil type, alliance, elevation, and inclination. The Akaike information criterion (AIC) was used to determine relative model quality, and variables that 
significantly increased the AIC value were excluded (Hosmer Jr et al. 2013). Finally, the deviance was determined using ANOVA.

In addition, the Random Forest (RF) method (Liaw and Wiener 2002) was used to assess the relationship among the explanatory variables (Table 2) and the response variable, i.e. the presence/absence of IAS in NFR. The explanatory variables used were alliance, soil type, bedrock class, relief, elevation, exposition, inclination, and soil layer depth (Table 2). The mean decrease in Gini coefficient was calculated to estimate the importance of each variable (Calle and Urrea 2010).

\section{Results}

\section{IAS in NFR and forest alliances}

In total, 16 IAS and 18 non-invasive alien species (AS) were recorded (Table 1$)$. The five most frequently occurring IAS were Impatiens parviflora $(\mathrm{n}=42 \mathrm{NFR})$ Robinia pseudoacacia $(\mathrm{n}=16 \mathrm{NFR})$, Solidago gigantea $(\mathrm{n}=11 \mathrm{NFR})$, Impatiens glandulifera $(\mathrm{n}$ $=6 \mathrm{NFR}$ ), and Acer negundo ( $\mathrm{n}=4 \mathrm{NFR}$ ). The four most frequently occurring AS were Quercus rubra ( $\mathrm{n}=3 \mathrm{NFR})$, Aesculus hippocastanum ( $\mathrm{n}=2 \mathrm{NFR})$, Atriplex sagittata $(\mathrm{n}=2 \mathrm{NFR})$, and Erechtites hieraciifolia $(\mathrm{n}=2 \mathrm{NFR})$. Figure 1 shows the proportion of sites with occurrences of IAS only, IAS and AS, or AS only, ranged from 0 to $100 \%$. The largest proportions of IAS were found in floodplain forest alliances, i.e. Alnion glutinosae (Malcuit, 1929) (100\%), Salicion albae (Soó, 1930) (93\%), Salicion cinereae (Müller \& Görs, 1958) (71\%), and Alnion incanae (Pawlowski in Pawlowski, Sokolowski and Wallisch 1928) (53\%). Furthermore, IAS occurred in relatively large proportions of sites inhabited by the following alliances: slope forests (Tilio-Acerion (Klika, 1955): 23\%), and oak and oak-hornbeam forests (Carpinion betuli (Issler, 1931): 19\%).

\section{Analysis of explanatory variables}

The final quasi-binomial model showed that soil type, alliance and elevation were the strongest explanatory variables $(\mathrm{p}<0.05)$ for the 189 sample plots with recorded IAS presence and 2,151 sample plots with recorded IAS absence. The probability of IAS presence was highest for the following soil types: pseudogley on unconsolidated sediments (130), gley (210), gray-alluvial soils (240), mature brown alluvial soils (250), and half bog (anmoor) (260) (Table 3). The probability of invasive species presence decreased with increasing elevation $(\mathrm{df}=1, \mathrm{p}<0.001)$ as well as with increasing slope inclination $(\mathrm{df}=1, \mathrm{p}<0.001)$.

The presence of Impatiens parviflora seems to be driving the model, however. We also applied the quasi-binomial model to I. parviflora and Robinia pseudoacacia, the two 

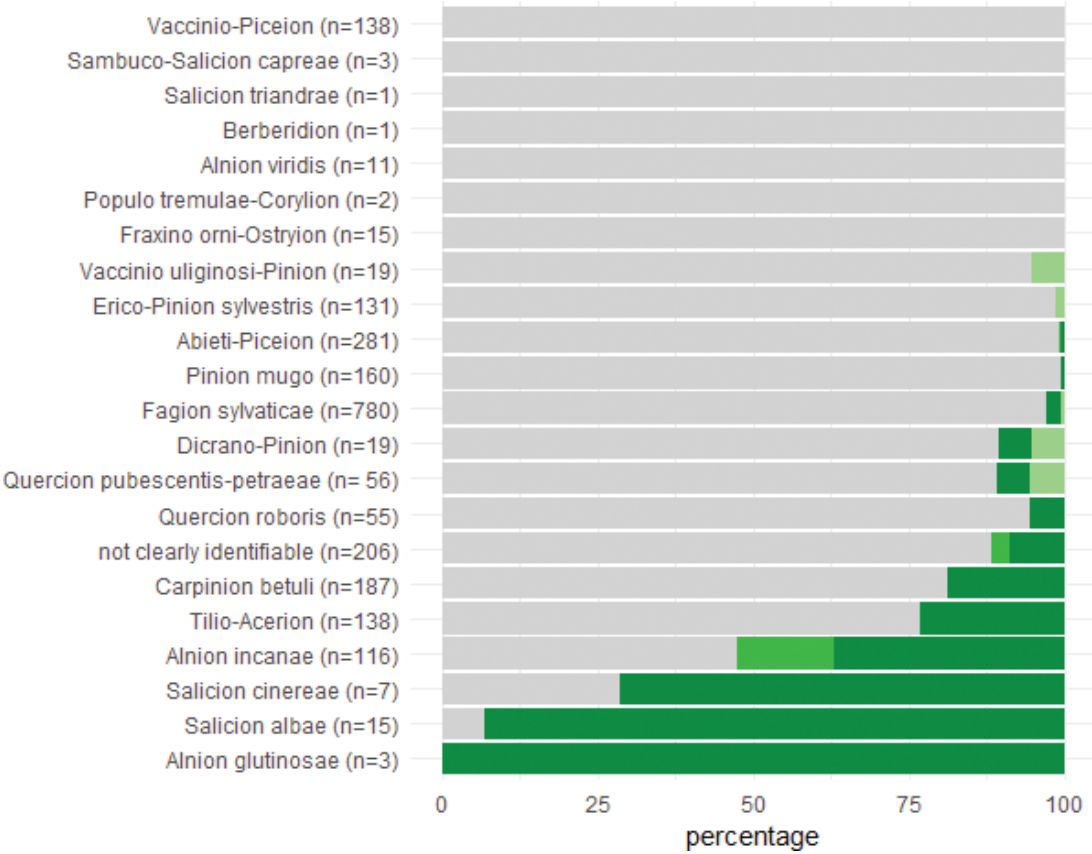

Figure I. Proportion of sites with occurrence of IAS (dark green), IAS and AS (green), AS (light green) and without IAS (grey) by forest alliances [\%] (Willner and Grabherr 2007) in 2,344 vegetation plots in the unmanaged natural forest sites of the NFR programme $(n=192)$. The highest proportions of IAS were found in floodplain forest alliances: Alnion glutinosae (Malcuit, 1929) (100\%), Salicion albae (Soó, 1930) (93\%), Salicion cinereae (Müller \& Görs, 1958) (71\%), Alnion incanae (Pawlowski in Pawlowski, Sokolowski and Wallisch 1928) (53\%).

species with the highest incidence in the vegetation sample set. The strongest explanatory variables for $I$. parviflora are soil type $(\mathrm{df}=32)$ and alliance $(\mathrm{df}=21)$ (Table 4$)$, while the strongest explanatory variables for $R$. pseudoacacia are bedrock class $(\mathrm{df}=5)$, relief $(\mathrm{df}=2)$ and elevation $(\mathrm{df}=1)$ (Table 5$)$. However, as elevation increases, the probability of $I$. parviflora and $R$. pseudoacacia being present decreases $(\mathrm{df}=1, \mathrm{p}<0.001)$. The most significant explanatory variable based on mean decrease in Gini was found to be elevation (51.63) followed by soil type (48.76), and alliance (32.10) (Figure 2). Relief (6.98) was the least significant among the test variables.

\section{Tree species composition and development}

In total, 11 native tree species and two invasive alien tree species were present in the 64 $\mathrm{AC}$ plots of the tree sampling. The native trees species with the highest occurrence by stem number were Fraxinus angustifolia, Acer campestre, and Ulmus spp. (Ulmus spp. includes $U$. glabra, $U$. minor, and $U$. laevis). In comparison, the tree species with the 
Table 3. Parameter estimates of generalized linear models (error structure $=$ quasi-binomial; link function $=$ logit) explaining the probability of the presence of IAS in NFR sites. Only significant explanatory variables occurring in the minimal adequate GLM were included in the model. Values are on the logit scale. ${ }^{*}=$ factors significant at the $\mathrm{p}<0.05$ level. Data included in the logistic regression model were not transformed.

\begin{tabular}{|c|c|c|c|c|c|c|}
\hline \multirow{2}{*}{$\frac{\text { Variable }}{\text { Soil type }}$} & \multicolumn{2}{|r|}{ Categories } & \multirow{2}{*}{$\begin{array}{r}\text { Estimate } \\
5.77 \mathrm{E}+03\end{array}$} & \multirow{2}{*}{$\begin{array}{c}\text { Std. error } \\
1.93 \mathrm{E}+03\end{array}$} & \multirow{2}{*}{$\begin{array}{l}\text { t value } \\
2.988\end{array}$} & \multirow{2}{*}{$\frac{\operatorname{Pr}(>|\mathbf{t}|)}{0.00}$} \\
\hline & 130 & Pseudogley on unconsolidated sed. & & & & \\
\hline & 250 & Mature, brown alluvial soil & $4.14 \mathrm{E}+03$ & $1.50 \mathrm{E}+03$ & 2.763 & 0.01 \\
\hline & 260 & Half-bog & $5.70 \mathrm{E}+03$ & $2.47 \mathrm{E}+03$ & 2.306 & 0.02 \\
\hline & 210 & Gley & $3.87 \mathrm{E}+03$ & $1.82 \mathrm{E}+03$ & 2.124 & 0.03 \\
\hline & 240 & Gray-alluvial soil & $3.28 \mathrm{E}+03$ & $1.64 \mathrm{E}+03$ & 1.996 & 0.05 \\
\hline & 80 & Minor Brown earth & $3.20 \mathrm{E}+03$ & $1.67 \mathrm{E}+03$ & 1.916 & 0.06 \\
\hline & 150 & Gley/Pseudogley on slopes & $3.39 \mathrm{E}+03$ & $1.98 \mathrm{E}+03$ & 1.712 & 0.09 \\
\hline & 21 & Colluvial deposits & $4.57 \mathrm{E}+03$ & $3.94 \mathrm{E}+03$ & 1.158 & 0.25 \\
\hline & 20 & Poor brown earth & $1.43 \mathrm{E}+03$ & $1.31 \mathrm{E}+03$ & 1.087 & 0.28 \\
\hline & 10 & Rankers & $1.34 \mathrm{E}+03$ & $1.32 \mathrm{E}+03$ & 1.016 & 0.31 \\
\hline & 31 & Minor calcaric cambisol & $1.30 \mathrm{E}+03$ & $1.42 \mathrm{E}+03$ & 0.91 & 0.36 \\
\hline & 30 & Eutrophic brown earth & $7.43 \mathrm{E}+02$ & $1.26 \mathrm{E}+03$ & 0.59 & 0.56 \\
\hline & 180 & Rendzinas & $-8.79 \mathrm{E}+02$ & $1.50 \mathrm{E}+03$ & -0.59 & 0.56 \\
\hline & 100 & Brown earth on loess & $1.40 \mathrm{E}+03$ & $2.66 \mathrm{E}+03$ & 0.53 & 0.60 \\
\hline & 120 & Pseudogley on solid bedrocks & $7.21 \mathrm{E}+02$ & $1.88 \mathrm{E}+03$ & 0.38 & 0.70 \\
\hline & 200 & Terra fusca & $-5.87 \mathrm{E}+02$ & $1.61 \mathrm{E}+03$ & -0.37 & 0.71 \\
\hline & 90 & Cohesive brown earth & $-1.87 \mathrm{E}+02$ & $1.82 \mathrm{E}+03$ & -0.10 & 0.92 \\
\hline & 190 & Mixed soil & $-1.71 \mathrm{E}+04$ & $2.73 \mathrm{E}+06$ & -0.01 & 0.99 \\
\hline & 40 & Semi-Podzols & $-1.47 \mathrm{E}+04$ & $3.86 \mathrm{E}+06$ & 0.00 & 1.00 \\
\hline & 22 & Podzolic brown soil & $-1.79 \mathrm{E}+04$ & $5.35 \mathrm{E}+06$ & 0.00 & 1.00 \\
\hline & 280 & Bog & $-1.49 \mathrm{E}+04$ & $4.74 \mathrm{E}+06$ & 0.00 & 1.00 \\
\hline & 160 & Loamy soil & $-1.83 \mathrm{E}+04$ & $7.09 \mathrm{E}+06$ & 0.00 & 1.00 \\
\hline & 181 & Pararendzina & $-1.78 \mathrm{E}+04$ & $7.46 \mathrm{E}+06$ & 0.00 & 1.00 \\
\hline & 270 & Low peat bog, bog general & $-1.43 \mathrm{E}+04$ & $6.81 \mathrm{E}+06$ & 0.00 & 1.00 \\
\hline & 220 & Alluvial soil, streamside marshes & $-1.78 \mathrm{E}+04$ & $1.09 \mathrm{E}+07$ & 0.00 & 1.00 \\
\hline & 60 & Substrate-induced Podzol & $-1.49 \mathrm{E}+04$ & $9.74 \mathrm{E}+06$ & 0.00 & 1.00 \\
\hline & 110 & Chromic luvisols & $-1.77 \mathrm{E}+04$ & $1.16 \mathrm{E}+07$ & 0.00 & 1.00 \\
\hline & 131 & Pseudogley on loess & $-1.76 \mathrm{E}+04$ & $1.18 \mathrm{E}+07$ & 0.00 & 1.00 \\
\hline & 50 & Climate-induced Podzol & $-9.51 \mathrm{E}+03$ & $7.87 \mathrm{E}+06$ & 0.00 & 1.00 \\
\hline & 92 & Slightly gleyed brown earth & $-1.54 \mathrm{E}+04$ & $1.64 \mathrm{E}+07$ & 0.00 & 1.00 \\
\hline & 202 & Cohesive calcaric cambisol & $-1.61 \mathrm{E}+04$ & $2.27 \mathrm{E}+07$ & 0.00 & 1.00 \\
\hline & 140 & Stagnogley & $-1.82 \mathrm{E}+04$ & $2.61 \mathrm{E}+07$ & 0.00 & 1.00 \\
\hline & 132 & Pseudogley on clay & $-1.31 \mathrm{E}+04$ & $2.09 \mathrm{E}+07$ & 0.00 & 1.00 \\
\hline & 81 & Brown podzolic soil & $-1.42 \mathrm{E}+04$ & $2.70 \mathrm{E}+07$ & 0.00 & 1.00 \\
\hline \multirow[t]{20}{*}{ Alliance } & & Fagion sylvaticae & $-2.31 E+03$ & $1.07 \mathrm{E}+03$ & -2.159 & 0.03 \\
\hline & & Quercion roboris & $-2.56 \mathrm{E}+03$ & $1.24 \mathrm{E}+03$ & -2.062 & 0.04 \\
\hline & & Dicrano-Pinion & $-2.84 \mathrm{E}+03$ & $1.58 \mathrm{E}+03$ & -1.793 & 0.07 \\
\hline & & Quercion pubescentis-petraeae & $-1.97 \mathrm{E}+03$ & $1.24 \mathrm{E}+03$ & -1589.00 & 0.11 \\
\hline & & Alnion incanae & $-1.58 \mathrm{E}+03$ & $1.26 \mathrm{E}+03$ & -1.253 & 0.21 \\
\hline & & Alnion glutinosae & $-2.62 \mathrm{E}+03$ & $2.32 \mathrm{E}+03$ & -1.129 & 0.26 \\
\hline & & Carpinion betuli & $-7.88 \mathrm{E}+02$ & $1.01 \mathrm{E}+03$ & -0.78 & 0.44 \\
\hline & & Salicion cinereae & $7.99 \mathrm{E}+02$ & $1.84 \mathrm{E}+03$ & 0.43 & 0.66 \\
\hline & & Tilio-Acerion & $-2.62 \mathrm{E}+02$ & $9.54 \mathrm{E}+02$ & -0.27 & 0.78 \\
\hline & & Salicion albae & $-4.22 \mathrm{E}+02$ & $1.78 \mathrm{E}+03$ & -0.24 & 0.81 \\
\hline & & Pinion mugo & $5.85 \mathrm{E}+02$ & $2.84 \mathrm{E}+03$ & 0.21 & 0.84 \\
\hline & & Vaccinio-Piceion & $-1.92 \mathrm{E}+04$ & $2.54 \mathrm{E}+06$ & -0.01 & 0.99 \\
\hline & & Erico-Pinion sylvestris & $-1.75 \mathrm{E}+04$ & $2.71 \mathrm{E}+06$ & -0.01 & 0.99 \\
\hline & & Vaccinio uliginosi-Pinion & $-1.95 \mathrm{E}+04$ & $6.15 \mathrm{E}+06$ & 0.00 & 1.00 \\
\hline & & Fraxino orni-Ostryion & $-1.79 \mathrm{E}+04$ & $6.62 \mathrm{E}+06$ & 0.00 & 1.00 \\
\hline & & Alnion viridis & $-1.36 \mathrm{E}+04$ & $7.98 \mathrm{E}+06$ & 0.00 & 1.00 \\
\hline & & Sambuco-Salicion capreae & $-1.80 \mathrm{E}+04$ & $1.07 \mathrm{E}+07$ & 0.00 & 1.00 \\
\hline & & Salicion triandrae & $-2.47 \mathrm{E}+04$ & $1.78 \mathrm{E}+07$ & 0.00 & 1.00 \\
\hline & & Berberidion & $-2.14 \mathrm{E}+04$ & $1.78 \mathrm{E}+07$ & 0.00 & 1.00 \\
\hline & & Populo tremulae-Corylion & $-1.85 \mathrm{E}+04$ & $1.78 \mathrm{E}+07$ & 0.00 & 1.00 \\
\hline \multicolumn{3}{|c|}{ Elevation } & $-6.46 \mathrm{E}+00$ & $1.33 \mathrm{E}+00$ & -4.847 & 0.00 \\
\hline \multicolumn{3}{|c|}{ Atan (inclination/100) } & $2.60 \mathrm{E}+03$ & $1.13 \mathrm{E}+03$ & 2.301 & 0.02 \\
\hline
\end{tabular}




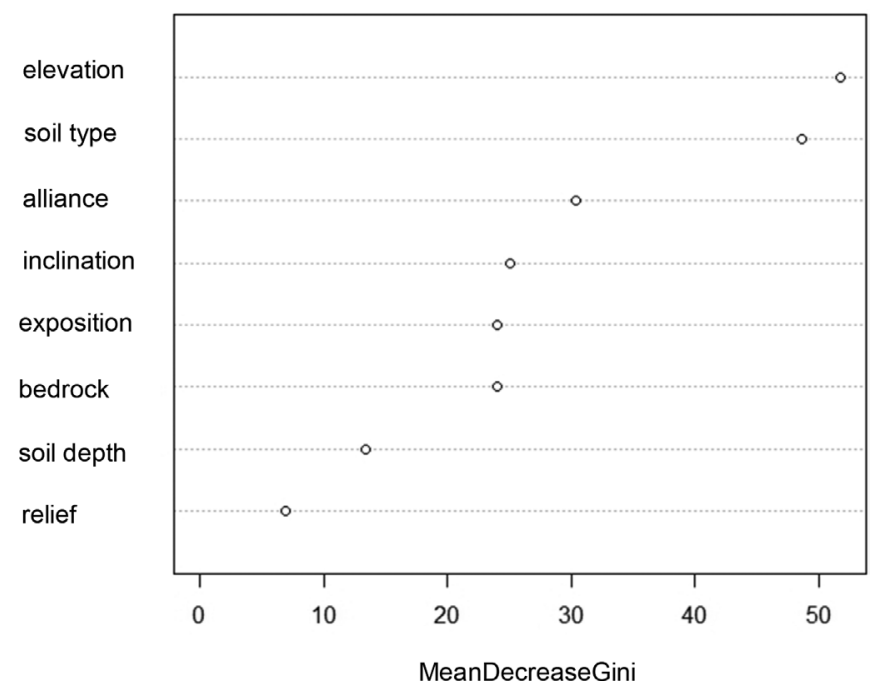

Figure 2. Variable significance plot for IAS presence by mean decrease in Gini values (MeanDecreaseGini) using the Random Forest model, ranked by significance. The points represent the mean decrease in Gini value, indicative of the importance of each variable. A higher value indicates the significance of that variable for predicting IAS occurrence in NFR sites.

highest basal areas were F. angustifolia, Populus spp. (Populus spp. includes P. alba, P. canescens, $P$. tremula, $P$. nigra, and $P . \times$ canadensis) and Quercus spp. (Quercus spp. includes $Q$. petraea and $Q$. robur), owing to a high proportion of large tree dimensions in $\mathrm{DBH}$. During the 15-year monitoring period, the average total stem number increased from 591 to 718 trees per ha and the averaged total basal area increased from 31.1 to $39.3 \mathrm{~m}^{2}$ per ha. The invasive tree species recorded were Fraxinus pennsylvanica and Acer negundo. Invasive tree species occurred in $8 \%$ (5 plots) of the total sampled area (64 plots). Figures 3, 4 compare the tree species composition in the AC plots by stem number and basal area between period 1 and period 2. Error bars indicate standard errors. The large error bars in Figure 3 indicate a low number of plots with a strong increase in stem number for $A$. negundo.

The species development data shows an increase in stem number for the native tree species F. angustifolia (from 126 to 177 trees per ha) and Ulmus spp. (Ulmus spp. includes U. glabra, U. minor, and U. laevis) (from 57 to 176 trees per ha), whereas a decrease was recorded for $A$. campestre (from 202 to 174 trees per ha), Populus spp. (Populus spp. includes $P$. alba, $P$. canescens, $P$. tremula, $P$. nigra, and $P . \times$ canadensis) (from 61 to 30 trees per ha) and Quercus spp. (Quercus spp. includes Q. petraea and Q. robur) (from 37 to 22 trees per ha). In terms of basal area, an increase in the proportion of F. angustifolia (from 11.7 to $17.0 \mathrm{~m}^{2}$ per ha) and Ulmus spp. (from 1.3 to $2.8 \mathrm{~m}^{2}$ per ha) was determined during the observation period, while the proportion of Salix spp. (Salix spp. includes $S$. alba, S. fragilis, and $S . \times$ rubens) was the only one to decrease slightly (from 1.1 to $0.9 \mathrm{~m}^{2}$ per ha). 
Table 4. Parameter estimates of generalized linear models (error structure = quasi-binomial; link function = logit) explaining the probability of the presence of Impatiens parviflora in NFR sites. Only significant explanatory variables occurring in the minimal adequate GLM were included in the model. Values are on the logit scale. $*$ = factors significant at the $\mathrm{p}<0.05$ level. Data included in the logistic regression model were not transformed.

\begin{tabular}{|c|c|c|c|c|c|c|}
\hline \multirow{2}{*}{$\begin{array}{l}\text { Variable } \\
\text { Alliance }\end{array}$} & \multicolumn{2}{|c|}{ Categories } & \multirow{2}{*}{$\begin{array}{c}\text { Estimate } \\
-1.39 \mathrm{E}+00\end{array}$} & \multirow{2}{*}{$\begin{array}{c}\text { Std. error } \\
1.10 \mathrm{E}+00\end{array}$} & \multirow{2}{*}{$\begin{array}{l}\text { t value } \\
-1.26\end{array}$} & \multirow{2}{*}{$\frac{\operatorname{Pr}(>|\mathbf{t}|)}{0.21}$} \\
\hline & & Abieti-Piceion & & & & \\
\hline & & Alnion glutinosae & $-1.92 \mathrm{E}+01$ & $6.83 E+03$ & 0.00 & 1.00 \\
\hline & & Alnion incanae & $-2.04 \mathrm{E}+00$ & $9.36 \mathrm{E}-01$ & -2.18 & 0,03 \\
\hline & & Alnion viridis & $-1.52 \mathrm{E}+01$ & $5.41 \mathrm{E}+03$ & 0.00 & 1.00 \\
\hline & & Berberidion & $-2.13 \mathrm{E}+01$ & $1.19 \mathrm{E}+04$ & 0.00 & 1.00 \\
\hline & & Carpinion betuli & $-1.68 \mathrm{E}+00$ & $6.85 \mathrm{E}-01$ & -2.46 & 0.01 \\
\hline & & Dicrano-Pinion & $-2.66 \mathrm{E}+00$ & $1.14 \mathrm{E}+00$ & -2.34 & 0.02 \\
\hline & & Erico-Pinion sylvestris & $-1.82 \mathrm{E}+01$ & $1.89 \mathrm{E}+03$ & -0.01 & 0.99 \\
\hline & & Fagion sylvaticae & $-2.29 \mathrm{E}+00$ & $7.87 \mathrm{E}-01$ & -2.91 & 0.00 \\
\hline & & Fraxino orni-Ostryion & $-1.89 \mathrm{E}+01$ & $4.35 \mathrm{E}+03$ & 0.00 & 1.00 \\
\hline & & Pinion mugo & $-4.49 \mathrm{E}-01$ & $2.06 \mathrm{E}+00$ & -0.22 & 0.83 \\
\hline & & Populo tremulae-Corylion & $-1.92 \mathrm{E}+01$ & $1.19 \mathrm{E}+04$ & 0.00 & 1.00 \\
\hline & & Quercion pubescentis-petraeae & $-2.52 \mathrm{E}+00$ & $9.16 \mathrm{E}-01$ & -2.75 & 0.01 \\
\hline & & Quercion roboris & $-2.58 \mathrm{E}+00$ & $8.88 \mathrm{E}-01$ & -2.90 & 0.00 \\
\hline & & Salicion albae & $-3.37 \mathrm{E}+00$ & $1.07 \mathrm{E}+00$ & -3.15 & 0.00 \\
\hline & & Salicion cinereae & $-2.33 \mathrm{E}+01$ & $5.73 \mathrm{E}+03$ & 0.00 & 1.00 \\
\hline & & Salicion triandrae & $-2.45 \mathrm{E}+01$ & $1.19 \mathrm{E}+04$ & 0.00 & 1.00 \\
\hline & & Sambuco-Salicion capreae & $-1.76 \mathrm{E}+01$ & $7.38 \mathrm{E}+03$ & 0.00 & 1.00 \\
\hline & & Tilio-Acerion & $-4.21 \mathrm{E}-01$ & $6.69 \mathrm{E}-01$ & -0.63 & 0.53 \\
\hline & & Vaccinio-Piceion & $-1.83 \mathrm{E}+01$ & $1.78 \mathrm{E}+03$ & -0.01 & 0.99 \\
\hline & & Vaccinio uliginosi-Pinion & $-3.12 \mathrm{E}+00$ & $5.86 \mathrm{E}+03$ & 0.00 & 1.00 \\
\hline \multirow[t]{32}{*}{ Soil type } & 80 & Minor Brown earth & $2.51 \mathrm{E}+00$ & $7.54 \mathrm{E}-01$ & 3.34 & 0.00 \\
\hline & 130 & Pseudogley on unconsolidated sediments & $2.84 \mathrm{E}+00$ & $7.55 \mathrm{E}-01$ & 3.77 & 0.00 \\
\hline & 250 & Mature. brown alluvial soil & $2.94 \mathrm{E}+00$ & $9.33 \mathrm{E}-01$ & 3.16 & 0.00 \\
\hline & 21 & Colluvial deposits & $4.36 \mathrm{E}+00$ & $1.76 \mathrm{E}+00$ & 2.48 & 0.01 \\
\hline & 180 & Rendzinas & $-1.60 \mathrm{E}+00$ & $6.78 \mathrm{E}-01$ & -2.36 & 0.02 \\
\hline & 150 & Hanggley. Hangpseudogley & $2.81 \mathrm{E}+00$ & $1.21 \mathrm{E}+00$ & 2.32 & 0.02 \\
\hline & 30 & Eutrophic brown earth & $-1.29 \mathrm{E}+00$ & $5.82 \mathrm{E}-01$ & -2.22 & 0.03 \\
\hline & 200 & Terra fusca & $-1.95 \mathrm{E}+00$ & $1.18 \mathrm{E}+00$ & -1.66 & 0.10 \\
\hline & 22 & Podzolic brown soil & $-1.83 \mathrm{E}+01$ & $3.73 \mathrm{E}+03$ & -0.01 & 0.10 \\
\hline & 240 & Gray-alluvial soil & $1.37 \mathrm{E}+00$ & $1.10 \mathrm{E}+00$ & 1.25 & 0.21 \\
\hline & 31 & Minor calcaric cambisol & $6.83 \mathrm{E}-01$ & $6.93 \mathrm{E}-01$ & 0.99 & 0.32 \\
\hline & 120 & Pseudogley on solid bedrocks & $-2.15 \mathrm{E}+00$ & $2.90 \mathrm{E}+00$ & -0.74 & 0.46 \\
\hline & 20 & Poor brown earth & $2.88 \mathrm{E}-01$ & $4.42 \mathrm{E}-01$ & 0.65 & 0.52 \\
\hline & 210 & Gley & $6.09 \mathrm{E}-01$ & $1.50 \mathrm{E}+00$ & 0.41 & 0.69 \\
\hline & 90 & Cohesive brown earth & $-4.18 \mathrm{E}-01$ & $1.11 \mathrm{E}+00$ & -0.38 & 0.71 \\
\hline & 190 & Mixed soil & $-1.79 \mathrm{E}+01$ & $1.89 \mathrm{E}+03$ & -0.01 & 0.99 \\
\hline & 40 & Semi-Podzols & $-1.60 \mathrm{E}+01$ & $2.76 \mathrm{E}+03$ & -0.01 & 1.00 \\
\hline & 280 & Bog & $-1.62 \mathrm{E}+01$ & $3.70 \mathrm{E}+03$ & 0.00 & 1.00 \\
\hline & 160 & Loamy soil & $-1.87 \mathrm{E}+01$ & $5.00 \mathrm{E}+03$ & 0.00 & 1.00 \\
\hline & 181 & Pararendzina & $-1.86 \mathrm{E}+01$ & $5.26 \mathrm{E}+03$ & 0.00 & 1.00 \\
\hline & 270 & Low peat bog, bog general & $-1.52 \mathrm{E}+01$ & $5.02 \mathrm{E}+03$ & 0.00 & 1.00 \\
\hline & 260 & Half-bog & $-1.43 \mathrm{E}+01$ & $5.52 \mathrm{E}+03$ & 0.00 & 1.00 \\
\hline & 220 & Alluvial soil, streamside marshes & $-1.82 \mathrm{E}+01$ & $7.28 \mathrm{E}+03$ & 0.00 & 1.00 \\
\hline & 60 & Substrate-induced Podzol & $-1.65 \mathrm{E}+01$ & $6.66 \mathrm{E}+03$ & 0.00 & 1.00 \\
\hline & 131 & Pseudogley on Loess & $-1.83 \mathrm{E}+01$ & $7.90 \mathrm{E}+03$ & 0.00 & 1.00 \\
\hline & 110 & Chromic luvisols & $-1.82 \mathrm{E}+01$ & $7.95 \mathrm{E}+03$ & 0.00 & 1.00 \\
\hline & 50 & Climate-induced Podzol & $-1.23 \mathrm{E}+01$ & $5.59 \mathrm{E}+03$ & 0.00 & 1.00 \\
\hline & 140 & Stagnogley & $-1.88 \mathrm{E}+01$ & $1.74 \mathrm{E}+04$ & 0.00 & 1.00 \\
\hline & 100 & Brown earth on loess & $-2.04 \mathrm{E}+01$ & $1.98 \mathrm{E}+04$ & 0.00 & 1.00 \\
\hline & 132 & Pseudogley on clay & $-1.51 \mathrm{E}+01$ & $1.49 \mathrm{E}+04$ & 0.00 & 1.00 \\
\hline & 202 & Cohesive calcaric cambisol & $-1.72 \mathrm{E}+01$ & $1.69 \mathrm{E}+04$ & 0.00 & 1.00 \\
\hline & 81 & Brown podzolic soil & $-1.56 \mathrm{E}+01$ & $1.85 \mathrm{E}+04$ & 0.00 & 1.00 \\
\hline \multirow[t]{2}{*}{ Relief } & \multicolumn{2}{|c|}{ Erosion } & $5,69 \mathrm{E}-01$ & $4.71 \mathrm{E}-01$ & 1.21 & 0.23 \\
\hline & \multicolumn{2}{|c|}{ Solid } & $7,17 \mathrm{E}-01$ & $3.54 \mathrm{E}-01$ & 2.03 & 0.04 \\
\hline \multicolumn{3}{|l|}{ Elevation } & $-4,77 \mathrm{E}-03$ & $8,92 \mathrm{E}-04$ & -5.35 & 0.00 \\
\hline \multicolumn{3}{|c|}{ Atan (inclination/100) } & $2,14 \mathrm{E}+00$ & $8,83 \mathrm{E}-01$ & 2.42 & 0.02 \\
\hline
\end{tabular}




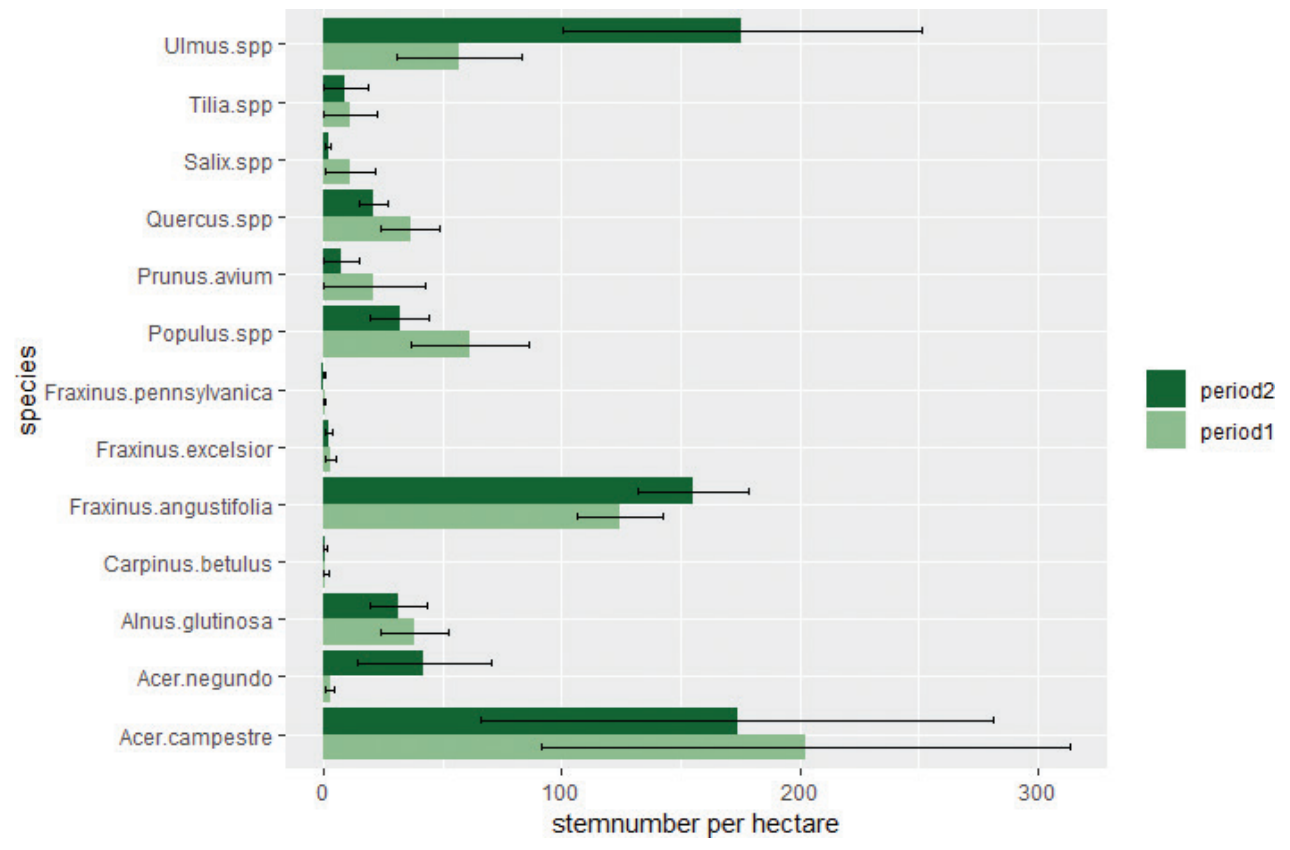

Figure 3. Changes in tree species composition in unmanaged floodplain forests (period 1: 1997 to 1999 - period 2: 2013 to 2014) using the angle count sampling method (Bitterlich, 1984). Average stem number per hectare in floodplain forests alongside the river March on 64 sample plots in 6 NFR in period 1 (light green) and period 2 (dark green); error bars denote standard errors. The large error bars indicate a low number of plots with a high increase in stem number for $A$. negundo. Ulmus spp. includes U. glabra, U. minor und U. laevis; Tilia spp. includes T. cordata, T. platyphyllos and T. $\times$ vulgaris; Quercus spp. includes $Q$. petraea, and $Q$. robur; Populus spp. includes $P$. alba, $P$. canescens, $P$. tremula, $P$. nigra, and $P . \times$ canadensis; Salix spp. includes $S$. alba, S. fragilis and $S . \times$ rubens.

Focusing on the IAS, the proportion of $F$ pennsylvanica in terms of both stem number and basal area was very low and remained stable during the observation period. The stem number for $A$. negundo increased from 3 to 42 trees per hectare, but its proportion in basal area only increased from 0.2 to $0.7 \mathrm{~m}^{2}$ per ha, indicating that the current tree population consists predominantly of small trees ranging from $\mathrm{DBH}$ 5 to $30 \mathrm{~cm}$.

\section{Natural tree species regeneration}

In total, IAS occurred in $0.4 \%(n=3)$ of the investigated regeneration site plots $(n=$ 784). The invasive species found were Robinia pseudoacacia, Ailanthus altissima, and Acer negundo, each on one plot. Individuals of $R$. pseudoacacia and A. altissima were found in the forest alliance Galio sylvatici-Carpinetum (Oberdorfer 1957) at elevations between 250 and $300 \mathrm{~m}$ above sea level. Acer negundo was found in the regeneration of the Fraxino pannonicae-Ulmetum floodplain forest alongside the river March at an 
Table 5. Parameter estimates of generalized linear models (error structure = quasi-binomial; link function $=$ logit) explaining the probability of the presence of Robinia pseudoacacia in NFR sites. Only significant explanatory variables occurring in the minimal adequate GLM were included in the model. Values are on the logit scale. ${ }^{*}=$ factors significant at the $\mathrm{p}<0.05$ level. Data included in the logistic regression model were not transformed.

\begin{tabular}{llcccc}
\hline \multicolumn{1}{c}{ Variable } & \multicolumn{1}{c}{ Categories } & Estimate & Std. error & t value & $\operatorname{Pr}(>|\mathbf{t}|)$ \\
\hline Bedrock class & Intermediate & $3.68 \mathrm{E}+00$ & $1.82 \mathrm{E}+00$ & 2.02 & 0.04 \\
& Carbonate & $3.44 \mathrm{E}+00$ & $1.75 \mathrm{E}+00$ & 1.97 & 0.05 \\
& Silicate & $1.86 \mathrm{E}+00$ & $1.80 \mathrm{E}+00$ & 1.03 & 0.30 \\
& Flood plain sediments & $9.13 \mathrm{E}-01$ & $1.32 \mathrm{E}+00$ & 0.69 & 0.49 \\
& Loess soil & $-1.45 \mathrm{E}+01$ & $6.73 \mathrm{E}+03$ & 0.00 & 1.00 \\
\multirow{4}{*}{ Relief } & Erosion & $-1.68 \mathrm{E}+01$ & $1.13 \mathrm{E}+03$ & -0.02 & 0,99 \\
& Solid & $-1.28 \mathrm{E}+00$ & $6.85 \mathrm{E}-01$ & -1.87 & 0,06 \\
Elevation & & $-2,03 \mathrm{E}-02$ & $5.54 \mathrm{E}-03$ & -3.66 & 0.00 \\
\hline
\end{tabular}

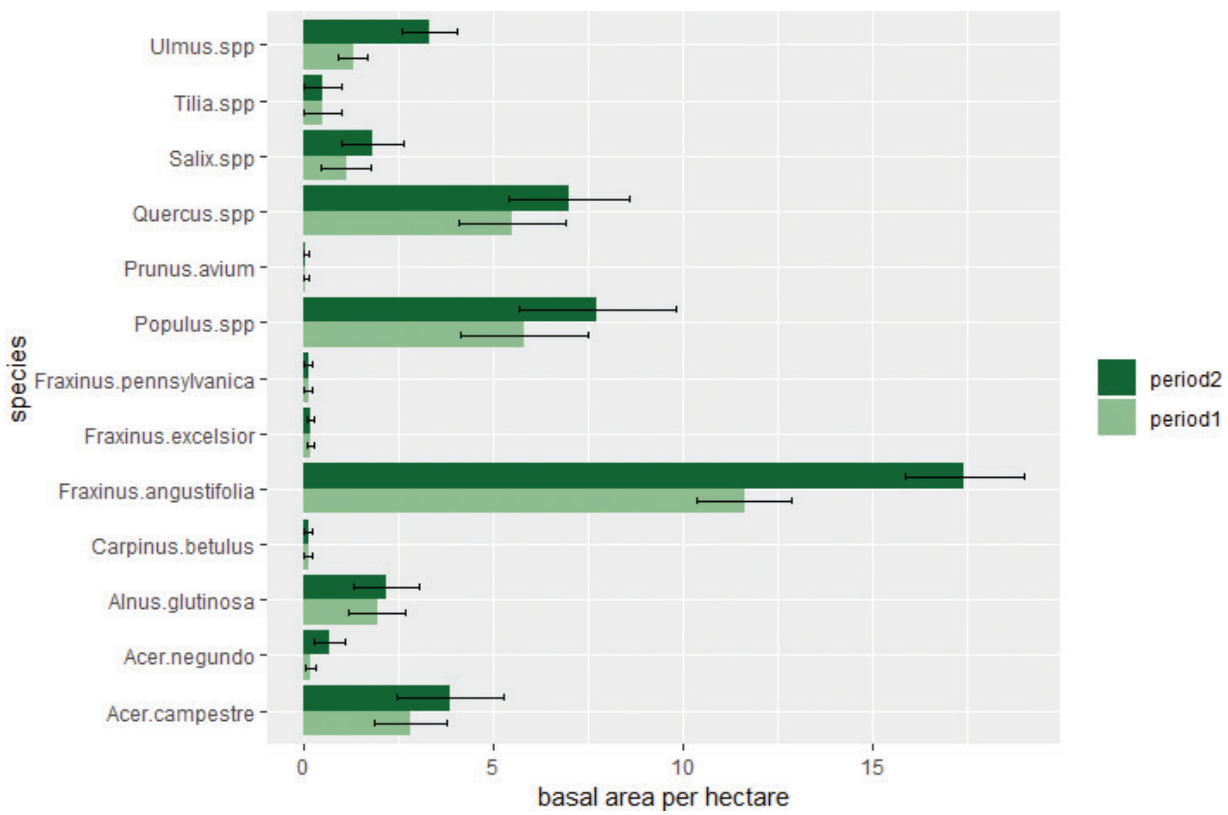

Figure 4. Changes in tree species composition in unmanaged floodplain forests (period 1: 1997-1999; period 2: 2013-2014) using the angle count sampling method (Bitterlich, 1984). Average basal area per hectare in floodplain forests alongside the river March on 64 sample plots in six NFR in period 1 (light green) and period 2 (dark green); error bars denote standard errors. Ulmus spp. includes U. glabra, U. minor, and U. laevis; Tilia spp. includes T. cordata, T. platyphyllos, and T. $\times$ vulgaris; Quercus spp. includes $Q$. petraea, and $Q$. robur; Populus spp. includes $P$. alba, P. canescens, P. tremula, $P$. nigra, and $P . \times$ canadensis; Salix spp. includes $S$. alba, S. fragilis, and $S . \times$ rubens.

elevation of $150 \mathrm{~m}$ above sea level. As this data is insufficient for further detailed statistical evaluation, vegetation surveys were used to analyse the spread of alien species in the forest communities of the NFR. 


\section{Discussion}

\section{The number and distribution of IAS}

The IAS and AS identified in both the herbaceous layer and the tree layer are not new to Europe; all of them are commonly known alien species in European temperate forests (Nehring et al. 2013; Braun et al. 2016; Wagner et al. 2017; Campagnaro et al. 2018). Most of the 16 IAS occurring in the NFR have a long history of introduction into Austria for ornamental purposes beginning in the $18^{\text {th }}$ century (Düll and Kutzelnigg 2005; Fischer 2008; Universität Innsbruck 2019). Of the alien plant species found in our study, 64\% originate from North America and 21\% from Asia. Encountering these species in the NFR plots examined for this study was therefore to be expected. Furthermore, the results show that $36 \%$ of the alien plant species recorded were phanerophytes. These findings are in line with Wagner et al. (2017), who found that phanerophytes are the most species-rich life-forms among alien plant species in European woodlands, possibly due to the high introduction pressure of alien trees since the $17^{\text {th }}$ century.

As was likewise to be expected, herbaceous IAS were found more frequently than tree species. Especially common were Impatiens parviflora (106 plots in 42 NFR), Solidago gigantea (38 plots in 11 NFR), and Bidens frondosa (31 plots in 4 NFR). The most common tree species were Fraxinus pennsylvanica (17 plots in 4 NFR), Robinia pseudoacacia (15 plots in $16 \mathrm{NFR}$ ), and Acer negundo (9 plots in 4 NFR). Interestingly, one of the most widespread IAS in Europe, Ailanthus altissima (the tree of heaven) (Pyšek et al. 2009; Boer 2012), occurred in only one regeneration plot. This may be on the one hand due to the low level of anthropogenic disturbances, e.g. transportation pathways, and on the other hand to closed canopy conditions in the NFR sites. In temperate Europe, the species $A$. altissima can form urban pioneer forests under sufficient light conditions and low competition (Kowarik and Säumel 2007), and its spread within the Danube floodplains is also mostly owed to human disturbances (Drescher and Ließ 2006; Campagnaro et al. 2018).

\section{Drivers influencing the occurrence of IAS in the herbaceous layer}

We conclude from the calculated statistical models that the best predictors for the number of IAS in unmanaged forests are alliance, elevation, and soil type (Table 3, Figure 2). Our results show that the probability of IAS occurrence in unmanaged forests decreases as elevation increases. Furthermore, unmanaged forests in lowlands with a low inclination are more likely to be invaded by IAS. These findings are in line with previous investigations showing that IAS preferably invade temperate European forests in warm climates and at lower elevations (Arévalo et al. 2005; Becker et al. 2005; Chytrý et al. 2009; Medvecká et al. 2018).

Besides elevation and alliance, soil type was found to be a highly significant variable. Our observations are similar across European woodlands, where I. parvi- 
flora has successfully established itself in a wide range of habitat niches with soils of intermediate to high nutrient content (Wagner et al. 2017). Comparison of Table 4 (Impatiens parviflora) with Table 3 (all IAS) reveals that Impatiens parviflora exhibits a different pattern of occurrence in terms of soil types. It prefers variants of brown earth $(21,30,80)$ and pseudogley $(130,150)$, but in contrast to most other IAS it shows no special affinity for riparian soils $(240,250)$. While riparian soils occur only in restricted areas, brown earth and pseudogley are very widespread in Austrian lowland forest areas (NFI 2009). Thus, the fact that I. parviflora is the most common of the IAS in Austria can be explained by its affinity for the predominant soil types in the area. Based on its high frequency, I. parviflora may constitute an example of species where a point of no return has been reached in Austrian forest ecosystems.

The abundance of IAS and AS (in total 34 alien plant species), especially of invasive alien tree species, in the unmanaged forest habitats investigated for this report is lower than in other European forest habitats (Richardson et al. 2007; Chytrý et al. 2009; Vilà et al. 2011; Nehring et al. 2013; Braun et al. 2016). Martin et al. (2009) conclude that unmanaged forests are actually more resistant to biological invasions, but that the speed of invasion by shade-tolerant species is comparatively lower than in grasslands and other habitats and is therefore often underestimated. The timescale of invasions by species with early-successional traits differs from the speed of invasions by shade-tolerant species in forest habitats (Martin and Marks 2006). All of the investigated NFR are closed-canopy forests containing large proportions of shade-tolerant species in the ground vegetation layer. Under the closed canopy of the unmanaged forest sites, the most abundant invasive species in the NFR network is I. parviflora, the small balsam, which is one of the most widespread invasive plants occurring in European temperate forests (Jarčuška et al. 2016). Impatiens parviflora occurred in a significantly larger number of NFR sites ( $n=42 \mathrm{NFR})$ than any of the other less shade-tolerant IAS identified. Given the risk of underestimating the slower invasion mechanisms in forest ecosystems, more emphasis on early detection of alien plant species is required to avoid an increase of propagule pressure in Central European forests (Essl et al. 2011; Nehring et al. 2013).

In many studies, human disturbances, which increase propagule pressure are mentioned as important predictors of the range and abundance of IAS in forest ecosystems (Walter et al. 2005; Pyšek et al. 2009; Berg et al. 2016). The direct anthropogenic influence on NFR sites is kept as low as possible, however, and is thus comparable to core zones of national parks or other strictly protected areas where any form of human disturbance is prohibited (Dudley 2008). Nevertheless, natural disturbances can and do occur, and thus may create gaps facilitating the pathways for invasions by IAS (Walter et al. 2005; Foxcroft et al. 2013). With endogenous (gradual, e.g. aging, decay) and exogenous (episodic, wind, fire, avalanches) disturbances being the main driving forces for development in forest reserves, the potential for invasions depends on the frequency and severity of the disturbances as well as the availability of propagules (Wohlgemuth et al. 2002; Maringer et al. 2012). 


\section{Tree species communities in floodplain forests}

Riparian areas, defined by Walter et al. (2005) as river banks and the edges of lakes, and floodplain forests are among the most-invaded habitat types in Europe (Planty-Tabacchi et al. 1996; Richardson et al. 2000; Tickner et al. 2001; Berg et al. 2016; Sosa et al. 2018). In floodplain forests, high nutrient levels and frequent disturbances due to flooding facilitate invasions, and rivers additionally serve as very effective propagation corridors for IAS (Kowarik 1992; Pyšek and Prach 1993; Schmiedel et al. 2013). The findings of this study confirm that natural floodplain forests are one of the forest types most vulnerable to biological invasions.

The occurrence of IAS was highest in the natural floodplain forest communities, with IAS were found in the herbaceous layer and the tree layer. Over the past 15 years, Fraxinus pennsylvanica and Acer negundo (a tree species of North American origin) increased in stem number and DBH in these communities. This increase may signal the beginning of species composition changes in the Fraxino pannonicae-Ulmetum community. Over the 15-year period examined in this study (1998/99 to 2013/14), the proportion of invasive tree species increased in the floodplain forest community.

The results of this study do not show any competitive interactions between alien and native floodplain plant species. Rather, they highlight that there has been an increase in total tree diversity. These observations are also reflected when considering the overall species composition of trees in floodplain NFR sites (Figs 3, 4).

The average stem number and basal area increased during the 15-year monitoring period, reflecting the observed high diversity and rapid development of tree species in riparian NFR. The numbers of individual tree species differ considerably between NFR sites, however. High stem numbers combined with low basal areas indicate a large proportion of small trees, whereas high basal areas indicate a large proportion of bigger trees. According to Figures 3, 4, the main tree species are Fraxinus angustifolia, Quercus spp., and Populus spp., trees with smaller DBH are Acer campestre, Acer negundo and Ulmus spp. While the proportion of $F$. pennsylvanica did not increase significantly during the observation period, the stem numbers of $A$. negundo did, although mostly small trees were found.

The most severe changes caused by invasive tree species were detected in NFR Herrschaftsspitz ( $n=9$ AC plots), where the number of $A$. negundo individuals increased from 20 per hectare in period 1 to 117 per hectare in period 2 (results not shown here). Acer negundo has spread widely across Europe and Central Asia (DAISIE 2017; GRIS 2018) since being introduced from North America for horticultural purposes in the $17^{\text {th }}$ century (Mędrzycki 2012). Acer negundo is commonly planted in parks and gardens in variegated forms (e.g. "Auratum", "Flamingo", "Aureomarginatum", "Variegatum") (van Gelderen and van Gelderen 1999). The impact of $A$. negundo on biodiversity and ecosystem functions of floodplain forests is high; it outcompetes native tree species by forming dense stands and through allelopathic effects on the soil (Mędrzycki 2012; Krevš et al. 2013; Hö̈le et al. 2014). Management measures for A. negundo have been widely applied, but are reported as not effective and too cost-intensive to be sustainable in the long 
term (De Poorter and Browne 2005; CABI 2019). Nevertheless, it should be pointed out that invasion by $A$. negundo at this intensity was observed only in one NFR site (NFR Herrschaftsspitz), which is located directly along the shoreline of the river March.

\section{Conclusion}

Given the presence of IAS with well-documented negative ecological impacts such as A. negundo, Robinia pseudoacacia, and Ailanthus altissima in comparably local spreads within the NFR sites on the one side and a high frequency of natural disturbances in the NFR sites on the other, the results of this study can be considered under a "no IAS management scenario" in the temperate climate of Central Europe. At high elevations ( $>800 \mathrm{~m}$ above sea level) almost no alien plant species were recorded. Nevertheless, the proportion of alien tree species in the sampled plots of the NFR is similar to that in the National Forest Inventory overall ( $<2 \%$ of the total forest cover). The non-intervention management policy in the NFR sites examined in this study offered an opportunity to observe changes in species composition, provide reference data for nature-based silviculture and contribute to management options in unmanaged forests.

In total, 16 IAS were identified in the study; this is in line with many other investigations into the spread of IAS in Europe. Similarities include a common set of IAS led by Impatiens parviflora, the small balsam, invading the ground vegetation of temperate forests. The findings of this study show that unmanaged forests at low elevations are not resistant to plant invasions. Instead, the monitoring of invasive plant species in NFR sites shows that biological plant invasions do occur in unmanaged temperate forest ecosystems, albeit at a slower pace than in many other habitat types. The results of the study also show that an absence of human disturbance may lower but not entirely mitigate the propagule pressure in forest ecosystems. Further studies are necessary to investigate the effects on propagule pressure. Nevertheless, it must to be taken into consideration that AC sampling may not be an appropriate methodology for evaluating spontaneous regeneration of IAS in NFR and that the observation period was comparatively short in the context of tree species development. Long-term studies with specific IAS monitoring are, therefore, necessary to achieve a better understanding of IAS development in unmanaged forest reserves. The aim of this study was to determine drivers for plant invasions in unmanaged European temperate forests. The explanatory variables alliance, elevation, bedrock class, soil type, and relief were found to be significant predictors for the presence of IAS. Ultimately, the findings of this study show that climatic limitation (elevation) is the main driver for the spread of IAS into unmanaged temperate European forests.

\section{Acknowledgements}

The BFW is acknowledged for providing the authors with access to its resources. We thank Christian Neureiter and many others who supported the data collection 
throughout the study period. Finally, we would like to thank Stephan Stockinger, Max Fancourt, and Elaine Paterson, whose methodological recommendations as well as comments on English language and style helped to improve this paper. We sincerely thank the two reviewers, Thomas Wohlgemuth and Giuseppe Brundu, whose comments/suggestions helped improve and clarify this manuscript.

\section{References}

Adamowski W (2008) Balsams on the offensive: the role of planting in the invasion of Impatiens species. In: Tokarska-Guzik B, Brock JH, Brundu G, Child L, Daehler CC, Pyšek (Eds) Plant Invasions: Human perception, ecological impacts and management. Backhuys Publishers, Leiden, 57-70.

Arévalo JR, Delgado JD, Otto R, Naranjo A, Salas M, Fernández-Palacios JM (2005) Distribution of alien vs. native plant species in roadside communities along an altitudinal gradient in Tenerife and Gran Canaria (Canary Islands). Perspectives in Plant Ecology, Evolution and Systematics 7(3): 185-202. https://doi.org/10.1016/j.ppees.2005.09.003

Bastian O (2013) The role of biodiversity in supporting ecosystem services in Natura 2000 sites. Ecological Indicators 24: 12-22. https://doi.org/10.1016/j.ecolind.2012.05.016

Becker T, Dietz H, Billeter R, Buschmann H, Edwards PJ (2005) Altitudinal distribution of alien plant species in the Swiss Alps. Perspectives in Plant Ecology, Evolution and Systematics 7(3): 173-183. https://doi.org/10.1016/j.ppees.2005.09.006

Berg C, Drescher A, Wagner V, Essl F (2016) Temporal trends in the invasions of Austrian woodlands by alien trees. Preslia 88(2): 185-200. http://www.preslia.cz/2016.html\#berg

BFW [Bundesforschungszentrum für Wald] (2018) Waldinventur des BFW. https://bfw.ac.at/ $\mathrm{rz} / \mathrm{bfwcms}$.web?dok=10485

BFW [Bundesforschungszentrum für Wald] (2019) NWR (Naturwaldreservate) Programm. http://www.naturwaldreservate.at/index.php/de/nwr-programm

Bitterlich W (1984) The relascope idea. Relative measurements in forestry. Commonwealth Agricultural Bureaux, Slough, 1-242.

Boer E (2012) Risk assessment Ailanthus altissima (Mill.) Swingle. https://www.nvwa.nl/binaries/nvwa/documenten/plant/planten-in-de-natuur/exoten/risicobeoordelingen/hemelboom/20130510_Risk_assessment_A+_altissima.pdf

Braun-Blanquet J (1928) Pflanzensoziologie - Grundzüge der Vegetationskunde. SpringerVerlag, Berlin Heidelberg, 330 pp. https://doi.org/10.1007/978-3-662-02056-2_1

Braun-Blanquet J (1932) Plant sociology: the study of plant communities. McGraw-Hill Book Company, New York/London, 476 pp.

Braun M, Schindler S, Essl F (2016) Distribution and management of invasive alien plant species in protected areas in Central Europe. Journal for Nature Conservation 33: 48-57. https://doi.org/10.1016/j.jnc.2016.07.002

Brundu G, Richardson DM (2016) Planted forests and invasive alien trees in Europe: a code for managing existing and future plantings to mitigate the risk of negative impacts from invasions. NeoBiota 30: 5-47. https://doi.org/10.3897/neobiota.30.7015 
CABI (2019) Invasive Species Compendium. https://www.cabi.org/isc.

Calle ML, Urrea V (2010) Letter to the editor: stability of random forest importance measures. Briefings in Bioinformatics 12(1): 86-89. https://doi.org/10.1093/bib/bbq011

Campagnaro T, Brundu G, Sitzia T (2018) Five major invasive alien tree species in European Union forest habitat types of the Alpine and Continental biogeographical regions. Journal for Nature Conservation 43: 227-238. https://doi.org/10.1016/j.jnc.2017.07.007

CBD (2016) Decision adopted by the Conference of the Parties to the Convention on Biological Diversity XIII/17. Synthetic biology. Synthetic Biology. CBD/COP/DEC/XIII/17: 1-4. https://www.cbd.int/doc/decisions/cop-13/cop-13-dec-17-en.pdf

Chirici G, Malak DA, Eggers J, Bastrup-Birk A, den Herder M, Lindner M, Zolli C (2014) Developing a forest naturalness indicator for Europe-Concept and methodology for a high nature value forest indicator. EEA Technical Report 13/2014: 1-60. https://www.eea.europa.eu/publications/developing-a-forest-naturalness-indicator

Chmura D (2004) Penetration and naturalisation of invasive alien plant species (neophytes) in woodlands of the Silesian Upland (southern Poland). Nature Conservation 60(3): 3-11. http://www.damianchmura.pl/wp-content/uploads/2011/12/Chmura-NC-2004.pdf

Chmura D, Sierka E (2007) The invasibility of deciduous forest communities after disturbance: a case study of Carex brizoides and Impatiens parviflora invasion. Forest Ecology and Management 242(2-3): 487-495. https://doi.org/10.1016/j.foreco.2007.01.083

Chytrý M, Pyšek P, Wild J, Pino J, Maskell LC, Vilà M (2009) European map of alien plant invasions based on the quantitative assessment across habitats. Diversity and Distributions 15(1): 98-107. https://doi.org/10.1111/j.1472-4642.2008.00515.x

DAISIE (2017) Delivering alien invasive species inventories for Europe. http://www.europealiens.org/speciesFactsheet.do?speciesId=17716\#

De Poorter M, Browne M (2005) The Global Invasive Species Database (GISD) and international information exchange: using global expertise to help in the fight against invasive alien species. In: Alford DV, Backhaus GF (Eds) Plant protection and plant health in Europe: introduction and spread of invasive species: International Symposium" Introduction and Spread of Invasive Species (Berlin, Germany), June 2005. CABI 81: 9-11.

Douda J, Boublík K, Slezák M, Biurrun I, Nociar J, Havrdová A, Brunet J (2016) Vegetation classification and biogeography of European floodplain forests and alder carrs. Applied Vegetation Science 19(1): 147-163. https://doi.org/10.1111/avsc.12201

Drescher A, Ließ N (2006) Control of alien woody species in the Danube National Park (Austria). The Example of Ailanthus altissima. Europ. Konferenz der Arbeitsgr. Neobiota: From Ecology to Conservation (Vienna, Austria). Poster. https:/www.researchgate.net/publication/284701348_Control_of_alien_woody_species_in_the_Danube_National_Park_ Austria_The_example_of_Ailanthus_altissima_Mill_Swingle

Dudley N (2008) Guidelines for applying protected area management categories. IUCN, Gland, 143 pp. https://doi.org/10.2305/IUCN.CH.2008.PAPS.2.en

Düll R, Kutzelnigg H (2005) Taschenlexikon der Pflanzen Deutschlands: ein botanisch-ökologischer Exkursionsbegleiter zu den wichtigsten Arten. Quelle \& Meyer, Leipzig, 578 pp.

EEA (2018) The Natura 2000 protected areas network. https://www.eea.europa.eu/themes/ biodiversity/natura-2000/the-natura-2000-protected-areas-network 
Essl F, Egger G, Ellmauer T, Aigner S (2002) Rote Liste der gefährdeten Biotoptypen Österreichs. NWV-Neuer Wiss. Verlag, Wien, 288 pp. http://www.umweltbundesamt.at/filead$\mathrm{min} /$ site/publikationen/M174.pdf

Essl F, Milasowszky N, Dirnböck T (2011) Plant invasions in temperate forests: Resistance or ephemeral phenomenon? Basic and Applied Ecology 12(1): 1-9. https://doi.org/10.1016/j. baae.2010.10.003

Essl F, Rabitsch W (2002) Neobiota in Österreich. Umweltbundesamt, Wien, 432 pp. http:// www.umweltbundesamt.at/fileadmin/site/publikationen/DP089.pdf

European Commission (2019) CIRCABC. https://ec.europa.eu/eusurvey/pdf/survey/159206? lang=EN\&unique $=291$ aebaf-61a4-4c01-b46d-727673dbc35e

European Commission (2015) Technical Report - 2015 - 088 NATURA 2000 and Forests. http://ec.europa.eu/environment/nature/natura2000/management/docs/Final\%20 Guide\%20N2000\%20\%20Forests\%20Part\%20I-II-Annexes.pdf

FAO (2015) Flobal Forest Resources Assessment. How are the world's forest changing? http:// www.fao.org/forest-resources-assessment/en/

Fischer MA (2008) Exkursionsflora für Österreich, Liechtenstein und Südtirol: Bestimmungsbuch für alle in der Republik Österreich, im Fürstentum Liechtenstein und in der Autonomen Provinz Bozen/Südtirol (Italien) wildwachsenden sowie die wichtigsten kultivierten Gefäßpflanzen (Farnpflanzen und Samenpflanzen) mit Angaben über ihre Ökologie und Verbreitung. Land Oberösterreich. OÖLandesmuseen, 1392 pp.

Foxcroft LC, Pyšek P, Richardson DM, Genovesi P (2013) Plant Invasions in Protected Areas - Patterns Problems, Challenges. Springer, Netherlands, 656 pp. https://doi. org/10.1007/978-94-007-7750-7

Frank G (2003) Naturwaldreservate: International beachtete Eichrichtung. Forstzeitung 114: 18-19. Frank G, Müller F (2003) Voluntary approaches in protection of forests in Austria. Environmental Science \& Policy 6(3): 261-269. https://doi.org/https://doi.org/10.1016/S14629011(03)00046-7

GBIF (2019) National alien species lists published through GBIF. https://www.gbif.org/ news/80f4taFSTu8kgkMU2qcqe/national-alien-species-lists-published-through-gbif

GISD (2018) The Global Invasive Species Database (GISD). http://www.iucngisd.org/

GISD (2019) The Global Invasive Species Database (GISD). http://www.iucngisd.org/

GRIS (2018) The Global Register of Invasive Species (GRIS). http://www.griis.org/

GRIS (2019) The Global Register of Invasive Species (GRIS). http://www.griis.org/

Guerra C, Baquero RA, Gutiérrez-Arellano D, Nicola GG (2018) Is the Natura 2000 network effective to prevent the biological invasions?. Global Ecology and Conservation 16( e00497). https://doi.org/10.1016/j.gecco.2018.e00497

Höfle R, Dullinger S, Essl F (2014) Different factors affect the local distribution, persistence and spread of alien tree species in floodplain forests. Basic and Applied Ecology 15(5): 426-434. https://doi.org/10.1016/j.baae.2014.07.007

Hosmer Jr DW, Lemeshow S, Sturdivant RX (2013) Applied logistic regression (Vol. 398). John Wiley \& Sons, Hoboken. https://doi.org/10.1002/9781118548387

IUCN (2018) Invasive alien species and sustainable development. https:/www.iucn.org/resources/issues-briefs/invasive-alien-species-and-sustainable-development 
Jarčuška B, Slezák M, Hrivnák R, Senko D (2016) Invasibility of alien Impatiens parviflo$r a$ in temperate forest understories. Flora 224: 14-23. https://doi.org/10.1016/j.flora.2016.06.005

Kettunen M, Genovesi P, Gollasch S, Pagad S, Starfinger U, ten Brink P, Shine C (2009) Technical support to EU strategy on invasive alien species (IAS). Institute for European Environmental Policy, Brussels, 44 pp.

Kilian W, Müller F, Starlinger F (1994) Die forstlichen Wuchsgebiete Osterreichs. FBVA-Berichte 82: 55-57. https://bfw.ac.at/300/pdf/1027.pdf

Kowarik I (1992) Einführung und Ausbreitung nichteinheimischer Gehölzarten in Berlin und Brandenburg und ihre Folgen für Flora und Vegetation. Ein Modell für die Freisetzung gentechnisch veränderter Organismen. Botanischer Verein von Berlin und Brandenburg e.V., 180 pp.

Kowarik I, Säumel I (2007) Biological flora of central Europe: Ailanthus altissima (Mill.) swingle. Perspectives in Plant Ecology, Evolution and Systematics 8(4): 207-237. https:// doi.org/10.1016/j.ppees.2007.03.002

Krevš A, Darginavičienė J, Gylytė B, Grigutytė R, Jurkonienė S, Karitonas R, Kučinskienė A, Pakalnis R, Sadauskas K, Vitkus R, Manusadžianas L (2013) Ecotoxicological effects evoked in hydrophytes by leachates of invasive Acer negundo and autochthonous Alnus glutinosa fallen off leaves during their microbial decomposition. Environmental Pollution 173: 75-84. https://doi.org/10.1016/j.envpol.2012.09.016

Landolt E, Bäumler B, Erhardt A, Hegg O, Klötzli FA, Lämmler W, Nobis M, RudmannMaurer K, Schweingruber FH, Theurillat J-P, Urmi E, Vust M, Wohlgemuth T (2010) Flora indicativa. Ecological inicator values and biological attributes of the flora of Switzerland and the Alps. Öökologische Zeigerwerte und biologische Kennzeichen zur Flora der Schweiz und der Alpen. Haupt Verlag, Bern, 376 pp.

Lauber K, Wagner G (2008) Flora Helvetica. Feddes Repertorium 108(5-6): 477-478. https:// doi.org/10.1002/fedr.19971080522

Levine JM, Adler PB, Yelenik SG (2004) A meta-analysis of biotic resistance to exotic plant invasions. Ecology Letters 7(10): 975-989. https://doi.org/10.1111/j.14610248.2004.00657.x

Liaw A, Wiener M (2002) Classification and regression by RandomForest. R News 2(3): 18 22. https://datajobs.com/data-science-repo/Random-Forest-[Liaw-and-Weiner].pdf

Londo G (1976) The decimal scale for releves of permanent quadrats. Vegetatio 33(1): 61-64. https://doi.org/10.1007/BF00055300

Maringer J, Wohlgemuth T, Neff C, Pezzatti GB, Conedera M (2012) Post-fire spread of alien plant species in a mixed broad-leaved forest of the Insubric region. Flora 207: 19-29. https://doi.org/10.1016/j.flora.2011.07.016

Martin PH, Canham CD, Marks PL (2009) Why forests appear resistant to exotic plant invasions: intentional introductions, stand dynamics, and the role of shade tolerance. Frontiers in Ecology and Environment 7(3): 142-149. https://doi.org/10.1890/070096

Martin PH, Marks PL (2006) Intact forests provide only weak resistance to a shade-tolerant invasive Norway maple (Acer platanoides L.). Journal of Ecology 94(6): 1070-1079. https:// doi.org/10.1111/j.1365-2745.2006.01159.x 
Mędrzycki P (2012) Invasive Alien Species Fact Sheet-Acer negundo. Online database of the European network on invasive alien species-NOBANIS. https://www.nobanis.org/globalassets/speciesinfo/a/acer-negundo/acer_negundo.pdf

Medvecká J, Jarolímek I, Hegedüšová K, Škodová I, Bazalová D, Botková K, Šibíková M (2018) Forest habitat invasions-who with whom, where and why. Forest Ecology and Management 409: 468-478. https://doi.org/10.1016/j.foreco.2017.08.038

Moore JJ (1962) The Braun-Blanquet System: a reassessment. Journal of Ecology 50(3): 761769. https://doi.org/10.2307/2257480

Mucina L (1993) Die Pflanzengesellschaften Österreichs. Teil III. Wälder und Gebüsche. Gustav Fischer Verlag, Jena, 353 pp.

National Pest Control Agencies (2015) Feral and Stray Cats Monitoring and Control, A Preliminary A11 Guideline Towards Good Practice. Biosecurity New Zealand, the Department of Conservation, Land Information New Zealand and Regional Councils, Wellington. https://www.bionet.nz/assets/Uploads/A11-Feral-and-Stray-Cats-2018-04-LR.pdf

Nehring S, Kowarik I, Rabitsch W, Essl F (2013) Naturschutzfachliche Invasivitätsbewertungen für in Deutschland wild lebende gebietsfremde Gefäßpflanzen. Bundesamt für Naturschutz, Bonn, 204 pp.

Nestroy O (1998) Stand der Beratungen über die Neufassung der Österreichischen Bodensystematik. Mitteilungen der Österreichischen Bodenkundlichen Gesellschaft 56: 79-85.

NFI [National Forest Inventory] (2009) Waldinventur. http://www.waldinventur.at.

Oberdorfer E (1952) Die Vegetationsgliederung des Kraichgaus. Beiträge zur naturkundlichen Forschung in Südwestdeutschland 11(1): 12-36.

Pagad S, Genovesi P, Carnevali L, Scalera R, Clout M (2015) IUCN SSC Invasive Species Specialist Group: invasive alien species information management supporting practitioners, policy makers and decision takers.Managment of Biological Invasions 6(2): 127-135. https://doi.org/10.3391/mbi.2015.6.2.03

Perrings C, Naeem S, Ahrestani F, Bunker DE, Burkill P, Canziani G, Elmqvist T, Ferrati R, Fuhrman J, Jaksic F, Kawabata Z (2010) Ecosystem services for 2020. Science 330(6002): 323-324. https://doi.org/10.1126/science.1196431

Planty-Tabacchi A, Tabacchi E, Naiman RJ, Deferrari C, Decamps H (1996) Invasibility of species-rich communities in riparian zones. Conservation Biology 10(2): 598-607. https:// doi.org/10.1046/j.1523-1739.1996.10020598.x

Potapov P, Hansen M, Laestadius L., Turubanova S, Yaroshenko A, Thies C, Smith W, Zhuravleva I, Komarova A, Minnemeyer S, Esipova E (2017) The last frontiers of wilderness: tracking loss of intact forest landscapes from 2000 to 2013. Science Advances 3: e1600821. https://doi.org/10.1126/sciadv.1600821

Press SJ, Wilson S (1978) Choosing between logistic regression and discriminant analysis. Journal of the American Statistical Association 73(364): 699-705. https://doi. org/10.2307/2286261

Pyšek P, Křivánek M, Jarošík V (2009) Planting intensity, residence time, and species traits determine invasion success of alien woody species. Ecology 90(10): 2734-2744. https:// doi.org/10.1890/08-0857.1 
Pyšek P, Lambdon PW, Arianoutsou M, Kühn I, Pino J, Winter M (2009) Alien vascular plants of Europe. Handbook of alien species in Europe. Springer, Netherlands, 43-61. https:// doi.org/10.1007/978-1-4020-8280-1

Pyšek P, Prach K (1993) Plant Invasions and the Role of Riparian Habitats: A Comparison of Four Species Alien to Central Europe. Journal of Biogeography 20: 413-420. https://doi. org/10.2307/2845589

R Core Team (2017) R: A language and environment for statistical computing. R Foundation for Statistical Computing, Vienna. https://www.r-project.org/

EU Regulation (2014) Regulation (EU) No 1143/2014 of the European Parliament and of the Council of 22 October 2014 on the prevention and management of the introduction and spread of invasive alien species. Official Journal of the European Union 57(317/35): 1-21.

Rejmánek M, Richardson DM (1996) What attributes make some plant species more invasive? Ecology 77(6): 1655-1661. https://doi.org/10.2307/2265768

Richardson DM, Holmes PM, Esler KJ, Galatowitsch SM, Stromberg JC, Kirkman SP, Pyšek P, Hobbs RJ (2007) Riparian vegetation: degradation, alien plant invasions, and restoration prospects. Diversity and Distributions 13(1): 126-139. https://doi.org/10.1111/j.13669516.2006.00314.x

Richardson DM, Pyšek P, Rejmánek M, Barbour MG, Panetta FD, West CJ (2000) Naturalization and invasion of alien plants: concepts and definitions. Diversity and Distributions 6(2): 93-107. https://doi.org/10.1046/j.1472-4642.2000.00083.x

Sabatini FM, Burrascano S, Keeton WS, Levers C, Lindner M, Pötzschner F, Verkerk PJ, Bauhus J, Buchwald E, Chaskovsky O, Debaive N, Horváth F, Garbarino M, Grigoriadis N, Lombardi F, Duarte IM, Meyer P, Midteng R, Mikac S, Mikoláš M, Motta R, Mozgeris G, Nunes L, Panayotov M, Ódor P, Ruete A, Simovski B, Stillhard J, Svoboda M, Szwagrzyk J, Tikkanen O-P, Volosyanchuk R, Vrska T, Zlatanov T, Kuemmerle T (2018) Where are Europe's last primary forests? Diversity and Distributions 24(10): 1426-1439. https:// doi.org/10.1111/ddi.12778

Schmidt W (2012) Wie naturnah sind Naturwaldreservate? Neophyten und Therophyten als geobotanische Indikatoren. Forstarchiv 83: 93-108. https://doi.org/10.4432/0300-4112-83-93

Schmiedel D, Huth F, Wagner S (2013) Using data from seed-dispersal modelling to manage invasive tree species: The example of Fraxinus pennsylvanica Marshall in Europe. Environmental Management 52(4): 851-860. https://doi.org/10.1007/s00267-013-0135-4

Seidl R, Schelhaas MJ, Rammer W, Verkerk PJ (2014) Increasing forest disturbances in Europe and their impact on carbon storage. Nature Climate Change 4(9): 806-810. https://doi. org/10.1038/NCLIMATE2318

Smith RD, Aradottir GI, Taylor A, Lyal C (2008) Invasive species management: what taxonomic support is needed. Global Invasive Species Programme, Nairobi, $44 \mathrm{pp}$.

Sosa B, Romero D, Fernández G, Achkar M (2018) Spatial analysis to identify invasion colonization strategies and management priorities in riparian ecosystems. Forest Ecology and Management 411: 195-202. https://doi.org/10.1016/j.foreco.2018.01.039

The EU Forest Strategy (2013) The EU Forest Strategy. European Commission, Brussels. https://ec.europa.eu/agriculture/forest/strategy_en 
Tickner DP, Angold PG, Gurnell AM, Mountford JO (2001) Riparian plant invasions: hydrogeomorphological control and ecological impacts. Progress in Physical Geography 25(1): 22-52. https://doi.org/10.1177/030913330102500102

Universität Innsbruck (2019) Merkblätter Universität Innsbruck: Neophyten - Tirol. https:// www.uibk.ac.at/botany/neophyten-tirol/problematische_arten/

Van Gelderen CJ, van Gelderen DM (1999) Maples for gardens: a color encyclopedia. Timber Press, Portland, 294 pp.

Vilà M, Espinar JL, Hejda M, Hulme PE, Jarošík V, Maron JL, Pergl J, Schaffner U, Sun Y, Pyšek P (2011) Ecological impacts of invasive alien plants: a meta-analysis of their effects on species, communities and ecosystems. Ecology Letters 14(7): 702-708. https://doi. org/10.1111/j.1461-0248.2011.01628.x

Walter J, Essl F, Englisch T, Kiehn M (2005) Neophytes in Austria: habitat preferences and ecological effects. In: Nentwig W, Bacher S, Cock MJW, Dietz H, Gigon A, Wittenberg R (Eds) Biological Invasions - from Ecology to Control. NeoBiota 6: 13-25.

Wagner V, Chytrý M, Jiménez-Alfaro B, Pergl J, Hennekens S, Biurrun I, Knollová I, Berg C, Vassilev K, Rodwell JS, Škvorc Z, Ewald J, Jansen F, Tsiripidis I, Botta Z, Casella L, Attorre F, Rašomavičius V, Ćušterevska R, Schaminée JHJ, Brunet J, Lenoir J, Svenning JC, Kacki Z, Petrášová-Šibíková M, Šilc U, García-Mijangos I, Campos JA, González FF, Wohlgemuth T, Onyshchenko V, Pyšek P (2017) Alien plant invasions in European woodlands. Diversity and Distributions 23: 969-981. https://doi.org/10.1111/ddi.12592

Willner W, Grabherr G (2007) Die Wälder und Gebüsche Österreichs. Spektrum Akademischer Verlag, Wien, 608 pp.

Wohlgemuth T, Bürgi M, Scheidegger C, Schütz M (2002) Dominance reduction of species through disturbance-a proposed management principle for central European forests. Forest Ecology and Management 166: 1-15. https://doi.org/10.1016/S0378-1127(01)00662-4 


\section{Appendix I}

\section{Legend of soil type classification (Nestroy 1998).}

asd

\begin{tabular}{|c|c|c|c|}
\hline Order & Classification & Soil type & Description \\
\hline \multirow[t]{13}{*}{ Hydromorphic } & Riparian soils & 220 & Alluvial soil, streamside marshes \\
\hline & & 240 & Gray-alluvial soil \\
\hline & & 250 & Mature, braun alluvial soil \\
\hline & Gley & 150 & Gley/Pseudogley on slopes \\
\hline & & 210 & Gley \\
\hline & Bog and half-bog & 260 & Half-bog \\
\hline & & 270 & Low peat bog, bog general \\
\hline & & 280 & Bog \\
\hline & Pseudogley & 120 & Pseudogley on solid bedrocks \\
\hline & & 130 & Pseudogley on unconsolidated sediments \\
\hline & & 131 & Pseudogley on Loess \\
\hline & & 132 & Pseudogley on clay \\
\hline & & 140 & Stagnogley \\
\hline \multirow[t]{23}{*}{ Terrestrial } & Loamy soil \& red clay & 160 & Loamy soil \\
\hline & & 190 & "Mixed soil" (Rendzina/ Terra fusca transition) \\
\hline & & 200 & Terra fusca \\
\hline & & 203 & Gleyed Terra fusca \\
\hline & Brown elevation earth & 20 & Poor brown earth \\
\hline & (Braunerde) & 22 & Podzolic brown soil \\
\hline & & 30 & Eutrophic brown earth \\
\hline & & 31 & Minor calcaric cambisol \\
\hline & & 80 & Minor Brown earth on unconsolidated sediments \\
\hline & & 81 & Brown podzolic soil on unconsolidated sediments \\
\hline & & 90 & Cohesive Brown earth on unconsolidated sediments \\
\hline & & 92 & Slightly gleyed brown earth on unconsolidated sediments \\
\hline & & 100 & Brown earth on loess \\
\hline & & 110 & Chromic luvisols (Para-brown earth) \\
\hline & & 202 & cohesive calcaric cambisol \\
\hline & Humid black soil & 171 & Humid black soil \\
\hline & Podzols & 40 & Semi-Podzols \\
\hline & & 50 & Climate-induced Podzol \\
\hline & & 60 & Substrate-induced Podzol \\
\hline & Rendzinas, Ranker & 10 & Rankers \\
\hline & & 180 & Rendzinas \\
\hline & & 181 & Pararendzina \\
\hline & Relocated soils & 21 & Colluvial deposits \\
\hline
\end{tabular}

